\title{
Transthoracic closure of ventricular septal defects guided by transesophageal echocardiography
}

\author{
Transözofageal ekokardiyografi essliğinde ventriküler septal defektlerin \\ transtorasik olarak kapatıması
}

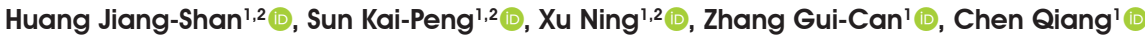 \\ Institution where the research was done: \\ Fujian Medical University, Union Hospital, Fuzhou, China
}

\section{Author Affiliations:}

'Department of Cardiovascular Surgery, Union Hospital, Fujian Medical University, Fuzhou, China

2Department of Cardiac Surgery, Fujian Provincial Maternity and Children's Hospital, Affiliated Hospital of Fujian Medical University, Fuzhou, China

\begin{abstract}
Background: This study aims to investigate the effectiveness and safety of transthoracic closure of ventricular septal defects totally guided by transesophageal echocardiography.

Methods: A total of 119 patients (62 males, 57 females; mean age $2.1 \pm 5.2$ years; range, 11 months to 50 years) who underwent transthoracic closure of ventricular septal defects in our center between April 2017 and November 2018 were included. All patients were evaluated in terms of the diameter and morphological features of ventricular septal defects via transesophageal echocardiography. During the procedure, transthoracic echocardiography was used as the only guiding tool for occluder implantation.

Results: Of the patients, 116 underwent successful transthoracic device closure procedure. Two patients were switched to surgical repair due to new-onset aortic regurgitation in one patient and severe arrhythmias after device release in the other patient. One patient underwent a second operation for occluder migration during the hospital stay. In the first attempt, 106 ventricular septal defect occluders were correctly positioned. Transthoracic echocardiography revealed the insecure position or significant residual shunting in 10 patients. The original device was replaced with an asymmetric device or a more extensive occluder, and satisfactory results were finally obtained. No complications such as new-onset aortic regurgitation, residual shunt, complete heart block, or device dislodgement occurred during follow-up.
\end{abstract}

Conclusion: Transthoracic closure of ventricular septal defects under the total guidance of transthoracic echocardiography is a safe and effective method.

Keywords: Transesophageal echocardiography, transthoracic device closure, ventricular septal defect.

\section{$\ddot{O Z Z}$}

Amaç: Bu çalışmada tamamen transözofageal ekokardiyografi eşliğinde ventriküler septal defektlerin transtorasik olarak kapatılmasının etkinliği ve güvenliliği değerlendirildi.

Çalışma planı: Nisan 2017 - Kasım 2018 tarihleri arasında merkezimizde ventriküler septal defektlerin transtorasik olarak kapatıldı $\breve{g}_{1}$ toplam 119 hasta (62 erkek, 57 kadın; ort. yaş 2.1 \pm 5.2 y1l; dağılım, 11 ay-50 yıl) çalışmaya alındı. Hastaların tümü ventriküler septal defektlerin çapı ve morfolojik özellikleri açısından transtorasik ekokardiyografi ile değerlendirildi. İşlem sırasında transtorasik ekokardiyografi oklüder yerleştirilmesi için kullanılan tek kılavuz araç idi.

Bulgular: Hastaların 116'sında transtorasik cihaz kapama işlemi başarılı idi. Bir hastada yeni başlangıçlı aort yetmezliği ve bir diğer hastada cihaz yerleştirildikten sonra şiddetli aritmiler nedeniyle olmak üzere, iki hastada cerrahi onarıma geçildi. Bir hastaya hastane yatışı sırasında oklüder migrasyonu nedeniyle ikinci bir ameliyat yapıldı. İlk girişimde 106 ventriküler septal defekt oklüderi doğru bir şekilde yerleştirildi. On hastada transtorasik ekokardiyografide güvenli olmayan yerleşim veya önemli düzeyde rezidüel şant izlendi. İlk takılan cihaz asimetrik cihaz veya daha kapsamlı bir oklüder ile değiştirildi ve nihayetinde memnun edici sonuçlar alındı. Takip sırasında yeni başlangıçlı aort yetmezliği, rezidüel şant, tam kalp bloku veya cihazın yerinden çıkması gibi komplikasyonlar gözlenmedi.

Sonuç: Ventriküler septal defektlerin tamamen transtorasik ekokardiyografi eşliğinde transtorasik olarak kapatılması güvenli ve etkili bir yöntemdir.

Anahtar sözcükler: Transözofageal ekokardiyografi, transtorasik cihazın kapatılması, ventriküler septal defekt.

Received: September 12, 2019 Accepted: February 07, 2020 Published online: April 22, 2020

Correspondence: Chen Qiang, MD. Department of Cardiovascular Surgery, Union Hospital, Fujian Medical University, 350001 Fuzhou, P. R. China. Tel: +86 13799376216 e-mail: chenqiang2228@163.com Turk Gogus Kalp Dama 2020;28(2):250-256 
Ventricular septal defects (VSDs) are one of the most common congenital heart diseases with approximately two cases per 1,000 live births..$^{[1,2]}$ Transcatheter device closure and conventional surgical repair for VSDs have been successfully used and reliably proven with minimal morbidity and no mortality. ${ }^{[3-6]}$ These two treatments have their own advantages and disadvantages and have their own irreplaceable characteristics.

In recent years, transthoracic device closure of VSDs totally guided by transesophageal echocardiography (TEE) has been widely used in China. ${ }^{[3,4]}$ Current clinical evidence have suggested that hybrid VSD closure is effective and safe with the advantages of a small incision, no X-ray exposure, easy to grasp and operate, and no additional equipment. ${ }^{[7-10]}$ Some researchers have also compared these three treatments and concluded that device closure is alternative to conventional surgical repair for patients with isolated pmVSD.$^{[11]}$ In many studies, TEE is used to assist in transcatheter device closure of VSDs. ${ }^{[12]}$ Also, TEE plays an important role in the device closure of VSDs. ${ }^{[13]}$

In the present study, we aimed to investigate the effectiveness and safety of transthoracic closure of VSDs under the total guidance of TEE.

\section{PATIENTS AND METHODS}

Between April 2017 and November 2018, a total of 119 patients with VSDs (62 males, 57 females; mean age $2.1 \pm 5.2$ years; range, 11 months to 50 years) who were scheduled for transthoracic device closure were included in this study. The detection and preliminary evaluation of VSDs were conducted by transthoracic echocardiography (TTE). Five patients were diagnosed with a doubly committed subarterial VSD, four patients with a muscular VSD, one patient with a residual shunt after the correction of tetralogy of Fallot, and another 109 patients with perimembranous VSD (pmVSD). Inclusion criteria were as follows: having clinical symptoms and/or TTE evidence of significant left-to-right shunts (Qp: Qs $>1.5$ ), an isolated VSD with a diameter ranging from 3 to $10 \mathrm{~mm}$ with a subaortic rim no less than $1 \mathrm{~mm}$, and/or significant heart chamber enlargement and/or mild pulmonary hypertension. Exclusion criteria included a nonrestrictive VSD with moderate-to-severe pulmonary hypertension, a diameter of VSD larger than $10 \mathrm{~mm}$ or smaller than $3 \mathrm{~mm}$, age below six months, presence of coexisting cardiac anomalies, or the refusal of patients or their relatives to sign the informed consent. A written informed consent was obtained from each patient or parent/legal guardian. The study protocol was approved by the Fujian Medical University, Ethics Committee (2009024). The study was conducted in accordance with the principles of the Declaration of Helsinki.

The VSD occluder used in this study was a double and self-expandable disc, which was manufactured by Shan Dong Visee Medical Apparatus Co. Ltd. or Shen Zhen Lifetech Scientific Ltd., China. The difference between these two brands of domestic occluders was not significant, and the choice of which occluder to be used was at the discretion of the surgeon. Depending on the design on the left disc, there were two types of occluders: symmetric and asymmetric. The details of these two occluders have been well described in previous reports..$^{[7-10]}$

\section{Operative technique}

All patients were administered general anesthesia and TEE with a 6T/9T multiplane probe by GE Vivid 7 (General Electric Company Corp., MA, USA) was used to identify the accurate size, morphological features, and visualization of the rims of the VSDs and particularly to evaluate the relationship between the defect and aortic valve. The maximal measured value of the VSD was used as the standard for the selection of the size of the occluder. ${ }^{[10]}$ The procedure of hybrid VSD closure was as follows: A lower inferior median sternotomy (approximately 2 to $5 \mathrm{~cm}$ ) was performed as the surgical approach (Figure 1). The pericardium was, then, opened and suspended to expose the part of the right ventricle. The location of the maximal response checked by slight finger palpation was chosen as the best puncture site. The proposed puncture site was extruded by tweezers and identified by TEE as

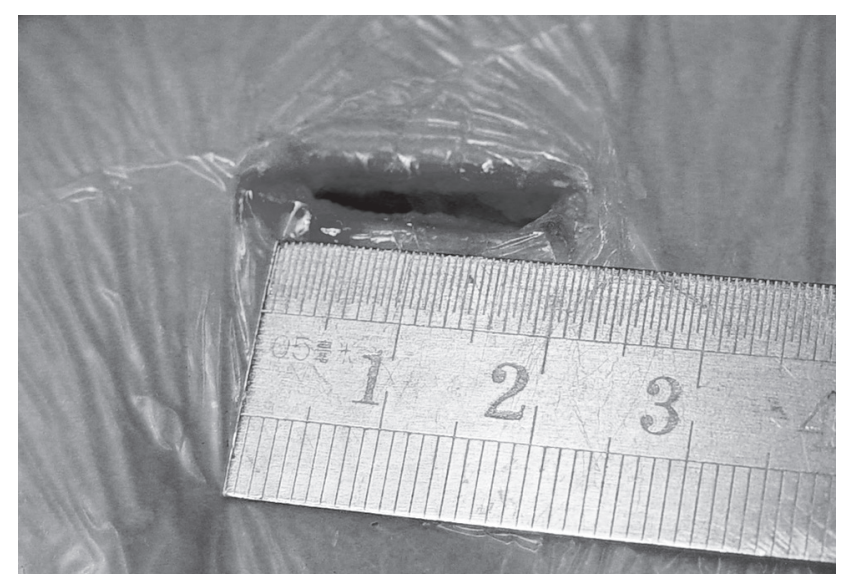

Figure 1. A lower inferior median incision. 


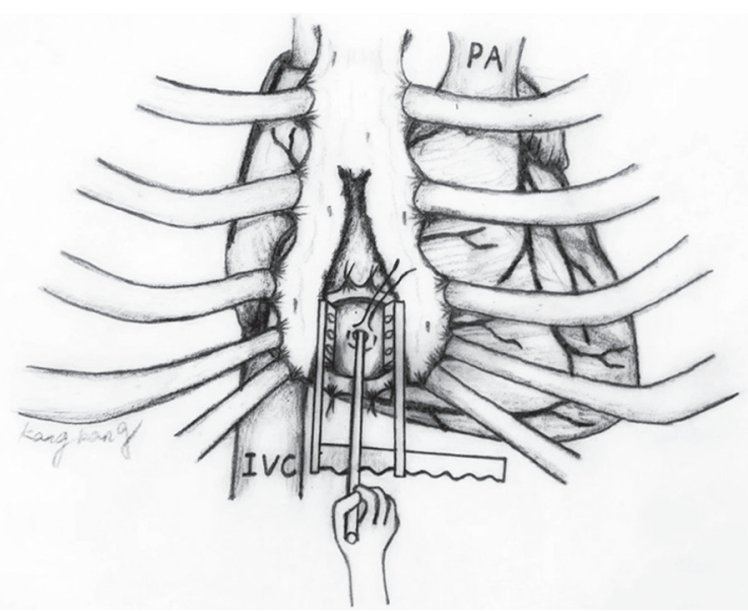

Figure 2. A schematic diagram of transthoracic device closure of a ventricular septal defect via a lower inferior median incision.

pointing to the VSD. Then, $5 / 0$ or $4 / 0$ prolene sutures were used to create a "pouch" at this location. A hollow needle was used to pierce the right ventricle through the proposed puncture site. A floppy wire was run through the needle into the right ventricle and was, then, advanced through the defect into the left ventricle. An appropriately sized delivery sheath was advanced along the wire into the left ventricle (Figure 2). The wire and inner core were removed, and the sheath was allowed to back bleed to ensure there was no air entrapment. The VSD occluder was immersed in saline and screwed with the delivery cable. Then, the occluder was advanced to the tip of the sheath by pushing the delivery cable. Under real-time TEE guidance, the left disc was deployed, and the sheath was pulled back slowly until the left disc approximated the ventricular septum, followed by the right disc deployment (Figure 3). The marker of the distal disc point should be downward while implanting the asymmetric device. Interference between the occluder and aortic valve should be avoided. Finally, residual shunting was assessed immediately by TEE after the implantation to decide whether the procedure should be completed or repeated.

All patients were discharged from hospital within two or three days after the hybrid device closure of VSDs. An anticoagulant such as acetylsalicylic acid was administered orally for about three months. Time to follow-up visit ranged from three months to one year. All patients underwent functional examination, TTE, and electrocardiography.
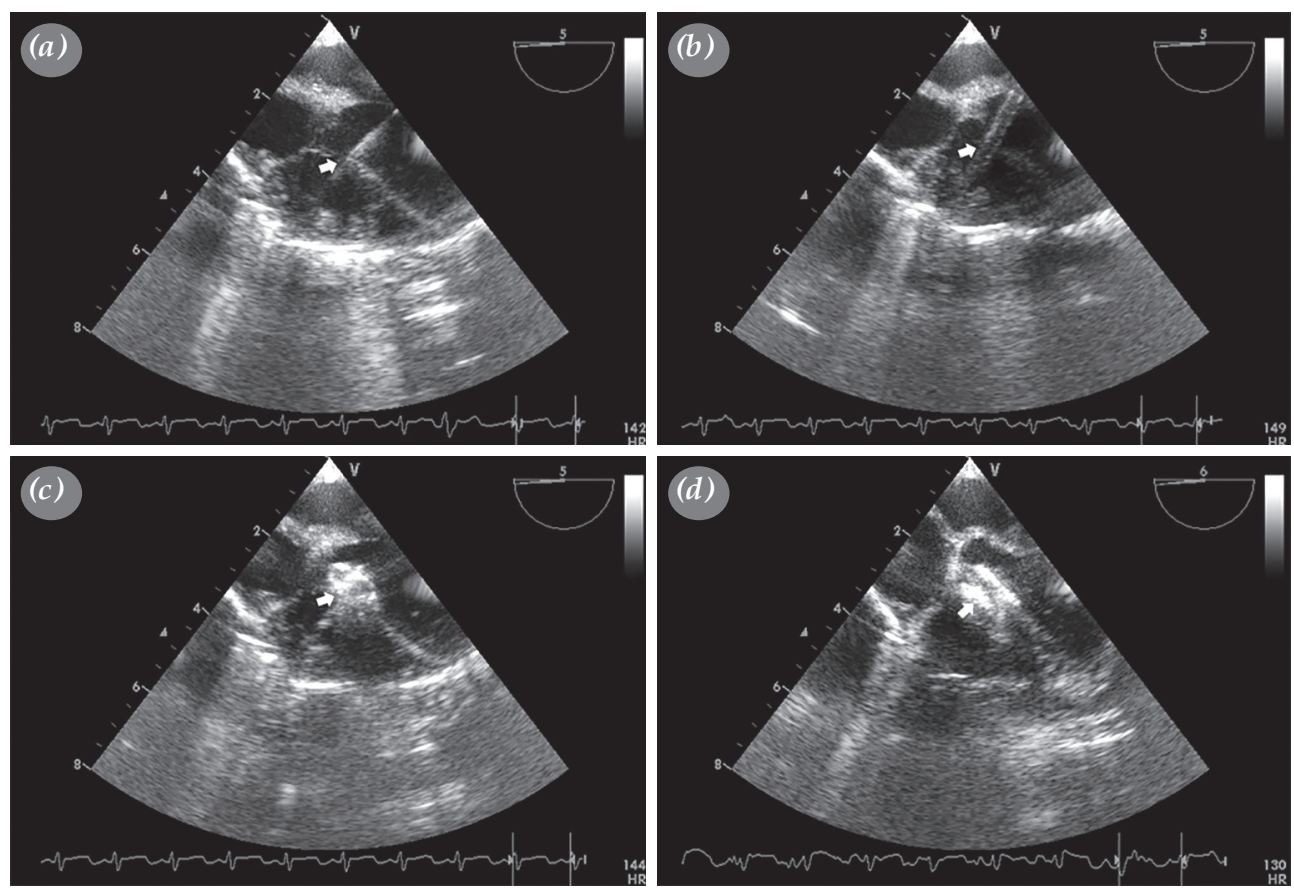

Figure 3. Transesophageal echocardiography showing the process of transthoracic device closure of a VSD. (a) A floppy wire positioned from right ventricle free wall into left ventricle cavity across VSD (arrow). (b) A sheath was advanced over wire into left ventricle across the VSD (arrow). (c) The left disc was deployed (arrow). (d) Both discs were deployed (arrow).

VSD: Ventricular septal defect. 


\section{Statistical analysis}

Statistical analysis was performed using the IBM SPSS version 23.0 software (IBM Corp., Armonk, NY, USA). Descriptive data were expressed in mean \pm standard deviation (SD), median (min-max) or number and frequency. A $p$ value of $<0.05$ was considered statistically significant.

\section{RESULTS}

Of the patients, 116 underwent successful transthoracic device closure procedure. Two patients were switched to surgical repair due to new-onset aortic regurgitation in one patient and complete atrioventricular block (AVB) during the procedure in the other patient. New-onset complete AVB disappeared immediately in this patient, when the device procedure was cancelled. One patient underwent a second operation for device migration during the hospital stay. In the first attempt, 106 VSD occluders were correctly positioned. In the remaining 10 patients (twice for $n=7$ and thrice for $n=3$ ), TEE revealed an unstable position, resulting in the impingement of the aortic valve or significant residual shunting. The original device was replaced with a more extensive or asymmetric VSD occluder and satisfactory results were finally obtained.

The mean diameter of the VSDs was $3.5 \pm 1.8$ (range, 3 to 9) $\mathrm{mm}$. The diameter of the sheath was 6 to $9 \mathrm{Fr}$, and the mean size of the occluder $6.1 \pm 2.6$ (range, 5 to 10$) \mathrm{mm}$. The mean duration of the procedure was $42.3 \pm 7.6$ (range, 30 to 55) $\mathrm{min}$. The device selected was the same size or 1 to 2 -mm larger than the VSD size evaluated by TEE. Considering the possible interference with the aortic valve, an asymmetric device was used in pmVSDs with aortic rims below $2 \mathrm{~mm}$ and in all doubly committed subarterial VSDs. There was a strong correlation between the defect size measured by TEE and the size of the occluder. The guidance of TEE provided a clear image of the occluder position in relation to the surrounding structures. After the procedure, we found a tiny residual flow in five patients. The overall immediate complete closure rate was $94.8 \%$.

During the follow-up period, no severe complications including sudden death, new-onset aortic valve regurgitation, tricuspid regurgitation, or thromboembolic events were observed. None of the patients developed new-onset complete AVB. The closure rate remained $100 \%$ during follow-up.

\section{DISCUSSION}

A VSD is a common congenital heart disease..$^{[1,2]}$ The conventional treatments include surgical repair and transcatheter device closure. Both treatments have their own merits and demerits with satisfactory therapeutic effects and have been widely used for a long time. ${ }^{[3-6]}$ In view of its special advantages, as an effective supplementary therapy, transthoracic device closure of VSDs totally guided by TEE has been frequently used in China in recent years. ${ }^{[7-10]}$ Compared to the two methods of device closure of VSDs, the core part of both methods is the use of an occluder, and the most remarkable difference between them is the establishment of different delivery tracks. The transcatheter method has no incision and quick recovery, but requires X-ray exposure and associated expensive machinery. The transthoracic approach, however, requires a small surgical incision; can be completely guided by ultrasonography and, therefore, does not require X-ray exposure; and is simple to be mastered and popularized.

Currently, several types of VSD occluders are used in the clinical setting, and different cardiac centers have different clinical experiences. Chungsomprasong et al. ${ }^{[14]}$ concluded that both the Amplatzer ${ }^{\circledR}$ VSD device and the Nit-Occlud ${ }^{\circledR}$ Lê VSD coil could be used for transcatheter closure of VSDs (pmVSDs and doubly committed subarterial VSDs). The former had the advantage of the closure of larger defects with immediate less residual shunt, but appeared to have a significant number of complete AVBs which required pacemaker implantation, while the latter had the advantage of the closure of both types of defects. In addition, Sayg1 et al. ${ }^{[15]}$ found two patients with pmVSD who required reintervention due to intractable hemolysis after the use of a Nit-Occlud ${ }^{\circledR}$ Lê VSD coil. El-Sisi et al. ${ }^{[16]}$ also reported that the Amplatzer duct occluder I and II were equally safe and effective in pmVSD closure and that the choice of which to use could be decided by preoperative TTE results. However, the Amplatzer duct occluder II was mostly limited to use in smaller VSDs. Similarly, Hua et al. ${ }^{[17]}$ reported using the Amplatzer vascular plug-II for closure of pmVSDs, which appeared to be a safe and effective treatment option. In our study, we used a domestic, less expensive occluder, which was explained in the previous section and we found that the domestic occluder was safe and effective.

During the procedure, the imaging of VSDs by TEE plays a crucial role. According to previous reports, TEE has an advantage over TTE in the measurement of the rims and dimensions of VSDs. ${ }^{[18,19]}$ We recommend TEE evaluation under general anesthesia before the procedure to ensure that the patient meets the inclusion criteria. It has been shown that TEE can accurately 
recognize the morphological variations of VSD. In the majority of patients with pmVSDs and muscular VSDs with an aortic rim above $2 \mathrm{~mm}$, the symmetric device should be used. For pmVSD patients and doubly committed subarterial VSD patients with some or total deficiency of the aortic rim, the asymmetric occluder should be chosen. Patients with an aortic rim below $2 \mathrm{~mm}$ have a higher risk for ineffective device closure and residual leakage. ${ }^{[20]}$ Some authors have also reported that these patients are unfit for device closure. ${ }^{[2]}$ Recently, An et al. ${ }^{[22]}$ reported that 28 patients with a doubly committed subarterial VSD underwent successful VSD closure and the authors concluded that such a procedure appeared to be a reliable technique with high efficiency. With an accurate measurement and careful operation, our patients with a doubly committed subarterial VSD also underwent a successful transthoracic device closure. In this study, in one patient in whom we switched to surgical closure during the procedure, an aortic rim value of $1 \mathrm{~mm}$ was demonstrated by TEE, and the impingement of the left disc on the aortic valve caused a new-onset aortic valve regurgitation following the occluder release. In the remaining five patients, doubly committed subarterial VSDs were closed successfully and no aortic regurgitation was found. Our experience indicated that, in patients in whom device closure can be completed, if there is any aortic valve regurgitation that occurs in the procedure, surgical repair should be recommended. An aortic rim of greater than $2 \mathrm{~mm}$ may allow stable occluder positioning and avoid interference with surrounding structures.

Comparing transthoracic and transcatheter device closure of VSD, the transthoracic procedure provides a shorter path and a more perpendicular angle to the defect. ${ }^{[23]}$ During both procedures of device closure, the most important step is to guide the wire through the VSD to establish the delivery track. Based on our experience with color Doppler imaging by TEE, the wire was easy to aim toward and through the VSD during the transthoracic procedure. Then, the wire entered the left ventricle and faced the mitral valve, when the VSD was located in the inlet ventricular septum region. In another condition, the VSD was located in the outlet ventricular septum region, and the wire went forward quickly through the aortic valve and stayed in the aorta. The real-time monitoring of occluder deployment is vital to avoid potential damage to the mitral/aortic valve. To adjust the occluder position, the operator can easily withdraw, rotate, and move the occluder immediately under the guidance of TEE. In the course of pulling back and centering the left disc, it is necessary to check any residual shunt before the release of the right disc. Approximately 10 to $20 \mathrm{~min}$ after occluder release is of utmost importance for monitoring. A small residual shunt through the junction of the occluder and rim of the defects or the device itself usually disappeared spontaneously after a couple of weeks, when endothelialization covered the surface of the occluder. When a significant residual shunt occurred, we withdrew the occluder into the delivery sheath and redeployed a larger one correctly. The domestic occluder which we used was elastic and resistant to damage, and no occurrence of dislodgement, wire fractures, or material breakdown were found, even when several attempts were made.

In some of the pmVSD patients, the VSD extended toward the posterior wall and tricuspid valve, which might lead to a deficiency of the rims in these directions or to interference in the function of the tricuspid valve. Patients with pmVSDs with ventricular septal aneurysms also underwent a successful closure attempt in this cohort. In these patients, there might be several breaches in the right ventricle. The diameter of the aneurysm should be carefully evaluated by TEE; then, the occluder might be released in the aneurysm to cover all breaches of the aneurysm, but not the position of the defect. In some other cases, the occluder should be chosen according to the diameter of the VSD. The left disc should completely cover the VSD, and the right disc should completely cover whole aneurysm, which ensures that the occluder is stable. Patients with multiple pmVSDs, which were usually divided into a few parts by fibrous tissue, also underwent transthoracic device closure. Transesophageal echocardiography could detect the most extensive defect, scale its stretch diameter, and guide the delivery sheath into the left ventricle through the most extensive defect. In some patients, several redeployment attempts through the different defects were attempted, when necessary. During the follow-up period, we demonstrated a successful closure in patients with multiple VSDs, and the adjacent holes were closed by covering with a single occluder.

The occluder selection is vital for transthoracic device closure according to the maximal size of the VSD measured by TEE. The size of the occluder should be equal to the maximum diameter of the VSD or 1 to 2-mm larger than the diameter of VSD. The rims of the VSD are elastic. When exposed to the pressure of the excess size of the occluder, the defects found were round in shape. Oversized occluders may lead to the occurrence of complete AVB. One patient experienced severe arrhythmias, which were thought to be a 
severe complication of device closure. We switched to surgical repair under cardiopulmonary bypass, and AVB disappeared. There was no unified conclusion on the mechanism of complete AVB, although many studies have suggested that mechanical compression and local tissue edema may be the causes. ${ }^{[24,25]}$ In our experience, we found that transthoracic procedure resulted in a low incidence of $\mathrm{AVB}$, which might be related to the operation process and to the selection of the appropriate size of the occluder.

Nonetheless, this study has some limitations. First, this is an observational study without a controlled design. Although there might be case selection bias and incomplete clinical data, it has still certain clinical significance. Second, this is a single-center study. Further multi-center studies with a larger sample size are needed to confirm these findings.

In conclusion, transthoracic device closure of ventricular septal defects under the total guidance of transesophageal echocardiography is a safe and effective method. In addition, transesophageal echocardiography plays an essential role for the procedure, facilitating the full assessment of cardiac anatomy and physiology relevant to the transthoracic device closure of VSDs and identifying most of adverse events which are likely to affect the successful outcomes of the procedure.

\section{Acknowledgement}

We highly acknowledge the contribution by the participating physicians: Dao-zhong Chen, Liang-wan Chen, Feng Lin, Qi-min Wang, Han-fan Qiu, Xue-shan Huang, Dong-shan Liao, Xiao-fu Dai, Zeng-chun Wang.

\section{Declaration of conflicting interests}

The authors declared no conflicts of interest with respect to the authorship and/or publication of this article.

\section{Funding}

This study was sponsored by Chinese National and Fujian Provincial Key Clinical Specialty Construction Programs.

\section{REFERENCES}

1. Xie D, Fang J, Liu Z, Wang H, Yang T, Sun Z, et al. Epidemiology and major subtypes of congenital heart defects in Hunan Province, China. Medicine (Baltimore) 2018;97:e11770

2. Glen S, Burns J, Bloomfield P. Prevalence and development of additional cardiac abnormalities in 1448 patients with congenital ventricular septal defects. Heart 2004;90:1321-5.

3. Narin N, Baykan A, Argun M, Özyurt A, Pamukçu Ö, Sezer $\mathrm{S}$, et al. Single-center results of the use of transcatheter closure for ventricular septal defects. Turk Gogus Kalp Dama 2015;23:448-53.
4. Santhanam H, Yang L, Chen Z, Tai BC, Rajgor DD, Quek SC. A meta-analysis of transcatheter device closure of perimembranous ventricular septal defect. Int J Cardiol 2018;254:75-83.

5. Aydemir NA, Harmandar B, Karaci AR, Sasmazel A, Bolukcu A, Saritas T, et al. Results for surgical closure of isolated ventricular septal defects in patients under one year of age. J Card Surg 2013;28:174-9.

6. Mongeon FP, Burkhart HM, Ammash NM, Dearani JA, Li Z, Warnes CA, et al. Indications and outcomes of surgical closure of ventricular septal defect in adults. JACC Cardiovasc Interv 2010;3:290-7.

7. Xing Q, Pan S, An Q, Zhang Z, Li J, Li F, et al. Minimally invasive perventricular device closure of perimembranous ventricular septal defect without cardiopulmonary bypass: multicenter experience and mid-term follow-up. J Thorac Cardiovasc Surg 2010;139:1409-15.

8. Ou-Yang WB, Wang SZ, Hu SS, Zhang FW, Zhang DW, Liu Y, et al. Perventricular device closure of perimembranous ventricular septal defect: effectiveness of symmetric and asymmetric occluders. Eur J Cardiothorac Surg 2017;51:478-82.

9. Hongxin L, Wenbin G, Lijun S, Zhengjun W, Hao L, Chengwei $\mathrm{Z}$, et al. Intraoperative device closure of secundum atrial septal defect with a right anterior minithoracotomy in 100 patients. J Thorac Cardiovasc Surg 2007;134:946-51.

10. Chen Q, Cao H, Zhang GC, Chen LW, Li QZ, Qiu ZH. Closure of perimembranous ventricular septal defects with intraoperative device technique: another safe alternative to surgical repair. Thorac Cardiovasc Surg 2013;61:293-9.

11. Fang GH, Chen Q, Hong ZN, Lin ZW, Zhang GC, Cao H, et al. The Comparison of Perventricular Device Closure with Transcatheter Device Closure and the Surgical Repair via Median Sternotomy for Perimembranous Ventricular Septal Defect. Ann Thorac Cardiovasc Surg 2018;24:308-14.

12. Bu H, Yang Y, Wu Q, Jin W, Zhao T. Echocardiographyguided percutaneous closure of perimembranous ventricular septal defects without arterial access and fluoroscopy. BMC Pediatr 2019;19:302.

13. Cao QL, Zabal C, Koenig P, Sandhu S, Hijazi ZM. Initial clinical experience with intracardiac echocardiography in guiding transcatheter closure of perimembranous ventricular septal defects: feasibility and comparison with transesophageal echocardiography. Catheter Cardiovasc Interv 2005;66:258-67.

14. Chungsomprasong P, Durongpisitkul K, Vijarnsorn C, Soongswang J, Lê TP. The results of transcatheter closure of VSD using Amplatzer® device and Nit Occlud® Lê coil. Catheter Cardiovasc Interv 2011;78:1032-40.

15. Saygı M, Şengül FS, Tanıdır İC, Kasar T, Haydin S, Güzeltaş A, et al. Management of intractable hemolysis after transcatheter ventricular septal defect closure with Nit Occlud® Lê ventricular septal defect coil. Turk Gogus Kalp Dama 2016;24:137-40.

16. El-Sisi A, Sobhy R, Jaccoub V, Hamza H. Perimembranous Ventricular Septal Defect Device Closure: Choosing Between Amplatzer Duct Occluder I and II. Pediatr Cardiol 2017;38:596-602. 
17. Hua N, Aquino P, Owada CY. Transcatheter closure of perimembranous ventricular septal defects with the Amplatzer Vascular Plug-II. Cardiol Young 2016;26:1194201.

18. Mercer-Rosa L, Seliem MA, Fedec A, Rome J, Rychik $\mathrm{J}$, Gaynor JW. Illustration of the additional value of realtime 3-dimensional echocardiography to conventional transthoracic and transesophageal 2-dimensional echocardiography in imaging muscular ventricular septal defects: does this have any impact on individual patient treatment? J Am Soc Echocardiogr 2006;19:1511-9.

19. Cossor W, Cui VW, Roberson DA. Three-dimensional echocardiographic en face views of ventricular septal defects: feasibility, accuracy, imaging protocols and reference image collection. J Am Soc Echocardiogr 2015;28:1020-9.

20. Zhang S, Zhu D, An Q, Tang H, Li D, Lin K. Minimally invasive perventricular device closure of doubly committed sub-arterial ventricular septal defects: single center longterm follow-up results. J Cardiothorac Surg 2015;10:119.

21. Yang L, Tai BC, Khin LW, Quek SC. A systematic review on the efficacy and safety of transcatheter device closure of ventricular septal defects (VSD). J Interv Cardiol 2014;27:260-72.

22. An G, Zhang H, Zheng S, Wang W, Wu Q, Xing Q. Minimally invasive surgical closure for doubly committed subarterial ventricular septal defects through a right subaxillary thoracotomy. Interact Cardiovasc Thorac Surg 2016;23:924-8.

23. Huang XS, Luo ZR, Chen Q, Yu LS, Cao H, Chen LW, et al. A Comparative study of perventricular and percutaneous device closure treatments for isolated ventricular septal defect: A chinese single-institution experience. Braz J Cardiovasc Surg 2019;34:344-51.

24. Butera G, Massimo C, Mario C. Late complete atriovenous block after percutaneous closure of a perimembranous ventricular septal defect. Catheter Cardiovasc Interv 2006;67:938-41.

25. Yip WC,Zimmerman F, Hijazi ZM. Heart block and empirical therapy after transcatheter closure of perimembranous ventricular septal defect. Catheter Cardiovasc Interv 2005;66:436-41. 